\title{
Recent Progress in Glass-Based Materials for Biomedical Applications
}

\author{
Tadashi KOKUBO \\ Institute for Chemical Research, Kyoto University, Uji-shi, Kyoto 611, Japan
}

医用生体材料としてのガラス関連材料の最近の進歩

小久保 正

京都大学化学研究所, 611 京都府宇治市五ヶ庄

\begin{abstract}
1971年にバイオグラスが発見されて以来，高強度，高切削性，短時間硬化能，フェリ磁性などの各種の機能を 示す種々の生体活性ガラス及び結晶化ガラスが開発されてきた．それらの中のいくつかのものは既に重要な骨修 復用埋入材料として臨床応用されており，癌治療に対してすら有効なことが明らかにされてきている. 生体活性 を支配する因子もかなり明らかにされてきた。これらの知見に基づければ，高勒性と低弾性率のような他の種々 の機能を示す新しい生体活性物質も近い将来ガラスから得られる可能性がある. 良好な成形性や，天然の外観， 放射性などの種々の機能を示す, 生体活性ではない不活性なガラスも歯冠や, 癌治療のための放射性担体などと して生医学的応用の分野で有用なことが明らかにされてきた. ガラス関連材料は次の10年の間に生体医用材料 として，更に重要な位置を占めるものと思われる.
\end{abstract}

[Received April 30, 1991]

\begin{abstract}
Since discovery of Bioglass in 1971, various kinds of bioactive glasses and glass-ceramics with different functions such as high mechanical strength, high machinability, fast-setting ability and ferrimagnetism have been developed. Some of them are already clinically used as important bone-repairing implants and also have been proved to be useful even for cancer treatments. Factors governing the bioactivity have been considerably revealed. On the basis of these findings, new kinds of bioactive materials with other different functions such as high fracture toughness as well as low elastic modulus also might be developed from glasses in near future. Non-bioactive but inert glasses and glass-ceramics with various functions such as good workability, natural appearance and radioactivity also have been shown to be useful for biomedical applications such as dental crown and radioactive carrier for a cancer treatment. Glass-based materials will occupy more important positions in biomedical materials in the next decade.
\end{abstract}

Key-words : Bioactive glass, Bioactive glass-ceramic, Bioactive cement, Bioactive composite, Bioactive and ferrimagnetic glass-ceramic, Radioactive glass sphere, Glass-ceramic dental crown, Hyperthermia, Artificial bone, Apatite, $\mathrm{CaO}-\mathrm{SiO}_{2-}$ $\mathrm{P}_{2} \mathrm{O}_{5}$, Bioactivity.

\section{Introduction}

G LASSES have been mainly used as container such as laboratory dishes, test tubes and ampoules in the medical field for long years. Since the discovery of Bioglass by Hench et al. in 1971, ${ }^{1)}$ however, much attention has been paid on glasses and glass-based materials as biomedical materials which can repair damaged living tissues and organs by interacting with biological systems. Generally, an artificial materials implanted into a bone defect is encapsulated by a non-calcified fibrous tissue, to be isolated from the surrounding bone. Hench et al., however, showed that some kinds of glasses contact directly with the surrounding bone without intervention of the fibrous tissue and form a tight chemical bond to the bone. This was the first manmade material discovered to bond to living tissue. Since then, various kind of bone-bonding, i.e. bioactive, glasses and glass-based materials with different functions such as high mechanical strength, high machinability and fast-setting ability have been developed. Some of them are already clinically used and occupy important positions in implant materials for repairing bone defects. Fundamental understanding of bonebonding mechanism of glasses and glass-ceramics have also largely progressed. This enables us to design new kinds of bioactive materials with various functions. Besides in bone-repairing field, glasses and glass-based materials can play an important role in other medical field. Some kinds of ferrimagnetic glass-ceramics and radioactive glasses have been proven to be useful for cancer treatments. Some kinds of inert glass-ceramics with appropriate color and transparency are clinically used as dental crown. More kinds of glasses and glass-based materials will be tailored for various kinds of biomedical applications in the next decade. Recent progress in glasses and glass-based materials for biomedical applications are reviewed.

2. Bioactive glasses and glass-ceramics

The glasses which were discovered to bond to liv- 
ing bone by Hench et al. in 1971 were based on $\mathrm{Na}_{2} \mathrm{O}, \mathrm{CaO}, \mathrm{SiO}_{2}$ and $\mathrm{P}_{2} \mathrm{O}_{5} \cdot{ }^{1)}$ They were named Bioglass ${ }^{\circledR}$ and their typical composition is $\mathrm{Na}_{2} \mathrm{O}$ 24.5, $\mathrm{CaO} 24.5, \mathrm{SiO}_{2} 45, \mathrm{P}_{2} \mathrm{O}_{5} 6 \mathrm{wt} \%$. The glass of this composition shows so high bioactivity that it can bond to even soft tissue. Hence this glass is successfully clinically used as artificial middle ear bone and alveolar ridge maintenance implant. ${ }^{2)}$ This, however, can not be used under load-bearing conditions, because its mechanical strength is not high.

In 1973, Brömer et al. reduced the alkaline oxide content of Bioglass-type glasses and precipitated crystalline apatite in the glasses by a heat treatment. ${ }^{3)}$ The resultant glass-ceramics, named Ceravital ${ }^{\circledR}$, showed a fairly high mechanical strengths, i.e. $150 \mathrm{MPa}$ at maximum in bending, but a little lower bioactivities than Bioglass. They can be used also as artificial middle ear bone. ${ }^{4)}$ Their mechanical strengths are, however, still not enough for uses under load-bearing conditions.

The natural bone is a composite in which apatite small crystals are effectively reinforced by collagen fibers. Kokubo et al. attempted to prepare a similar composite by crystallization of a glass,5),6) in 1982. In this attempt, $\beta$-wollastonite $\left(\mathrm{CaO} \cdot \mathrm{SiO}_{2}\right)$ having a silicate chain structure was chosen as the phase for reinforcing apatite crystals. A heat treatment of a glass powder compact of the composition $\mathrm{MgO}$ 4.6, $\mathrm{CaO} 44.7, \mathrm{SiO}_{2} 34.0, \mathrm{P}_{2} \mathrm{O}_{5} 16.2, \mathrm{CaF}_{2} 0.5 \mathrm{wt} \%$ gave a dense and homogeneous composite in which $38 \mathrm{wt} \%$ of oxyfluorapatite $\left(\mathrm{Ca}_{10}\left(\mathrm{PO}_{4}\right)_{6}\left(\mathrm{O}, \mathrm{F}_{2}\right)\right)$ and $34 \mathrm{wt} \%$ of $\beta$-wollastonite both in a form of rice grain-like particles (50 to $100 \mathrm{~nm}$ in sizes) were dispersed in a $\mathrm{MgO}-\mathrm{CaO}-\mathrm{SiO}_{2}$ glassy matrix, as shown in Fig. 1. The resultant glass-ceramic, named $\mathrm{A}-\mathrm{W}$, showed a bending strength of about $200 \mathrm{MPa}$ in the air environment, ${ }^{7}$ which is higher than that (160 MPa)

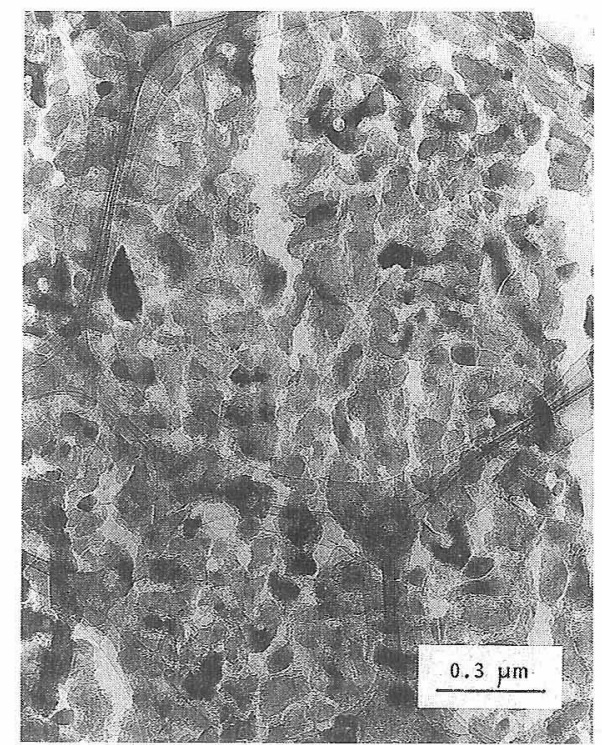

Fig. 1. Transmission electron micrograph of glass-ceramic $\mathrm{A}-\mathrm{W}$. of the human cortical bone, as well as a fairly low mechanical fatigue in body environment. ${ }^{8)}$ Consequently, it was, for example, expected that when a bending stress of $65 \mathrm{MPa}$ is continuously applied in the body environment, glass-ceramic $\mathrm{A}-\mathrm{W}$ can withstand it for over $10 \mathrm{yr}$, whereas the parent glass, a glass-ceramic containing only the apatite and a dense sintered hydroxyapatite are all broken in only 1 min. During unloaded period, glass-ceramic A-W rather showed an increase in mechanical strength in the body environment. Hence, a greatly prolonged life time than estimated can be expected in practical cases. The sintered hydroxyapatite is a bioactive crystalline ceramic ${ }^{9)}$ most widely used. A rectangular specimen of glass-ceramic A-W which was implanted into a tibia of rabbit was so tightly bonded to the surrounding bone that the fracture did not occur at the interface between them but did in the living bone when a tensile stress was applied to the interface. ${ }^{10)}$ Granular particles of glass-ceramic A$\mathrm{W}$ which were implanted into a tibia of rabbit were covered with a newly grown bone at much higher rate than those of the sintered hydroxyapatite, i.e. about $90 \%$ of the surfaces of the former was covered in 4 weeks, whereas only $60 \%$ of those of the later even after 16 weeks. ${ }^{11)}$ Because of these mechanical and biological advantages, glass-ceramic $\mathrm{A}-\mathrm{W}$ is already clinically used as artificial iliac crests ${ }^{12)}$ and is successfully subjected to clinical trials for uses as artificial vertebrae, ${ }^{13)}$ intervertebral discs and bone fillers. ${ }^{14)}$ Some examples of artificial bones of glassceramic $A-W$ are shown in Fig. 2. Figure 3 shows a artificial bertebra of this glass-ceramic which substituted for a part of vertebra of a sheep and tightly bonded to the surrounding cancellous bone.

Another type of apatite- and wollastonite-containing glass-ceramic, named Ilmaplant ${ }^{\circledR}-\mathrm{Ll}$, was prepared by Berger et al. ${ }^{15)}$ by a heat treatment of a bulk glass of a different composition. It is clinically used in maxilla-facial areas.

In 1983, Hölland et al. developed a bioactive and

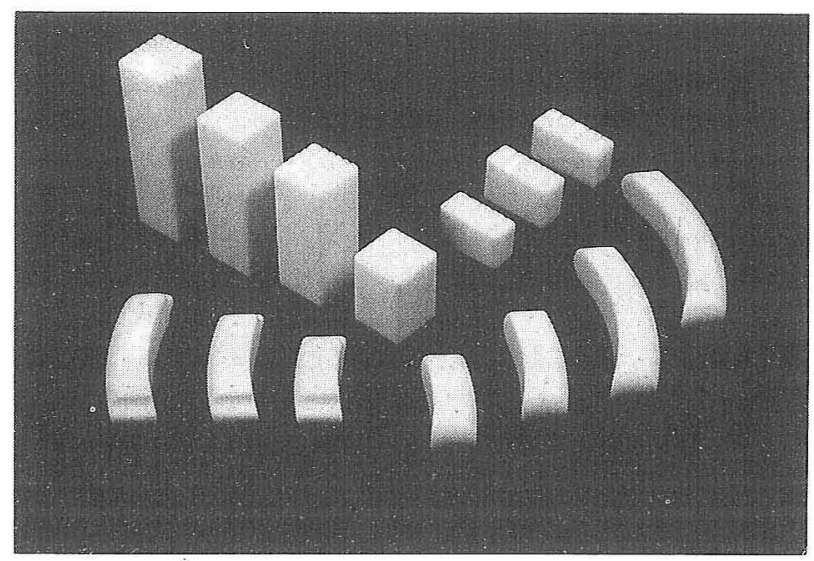

Fig. 2. Some examples of artificial vertebrae (left upper part), intervertebral discs (right upper part) and iliac crests (lower part) of glass-ceramic A-W. 


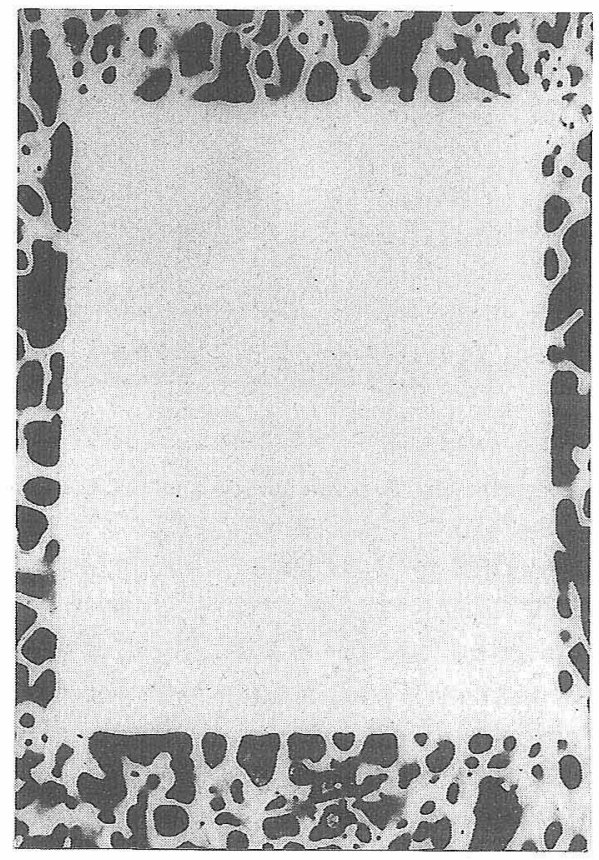

Fig. 3. Glass-ceramic $A-W$ which substituted for a vertebra of a sheep and bonded to the surrounding cancellous bone (contact microradiograph).

machinable glass-ceramic, named Bioverit ${ }^{\circledR}$, containing apatite and phlogopite $\left((\mathrm{Na}, \mathrm{K}) \mathrm{Mg}_{3}\left(\mathrm{AlSiO}_{10}\right)\right.$ $\left.\mathrm{F}_{2}\right){ }^{16)}$ It is also clinically used as artificial vertebra. ${ }^{17)}$

\section{Bone-bonding mechanism of glasses and glass-ceramics}

All bioactive glasses ${ }^{18)-22)}$ and glass-ceramics ${ }^{23)-26)}$ hitherto known bonded to living bone through a thin layer rich in calcium and phosphorus which was formed on their surfaces in the body. The Ca, P-rich layer was identified as an apatite layer by X-ray microdiffraction ${ }^{27)}$ and electron diffraction techniques. ${ }^{28)}$ Figure 4 shows a transmission electron micrograph of the interface between glass-ceramic $\mathrm{A}-\mathrm{W}$ implanted into a rat tibia and the surrounding bone. ${ }^{28)}$ It can be seen from Fig. 4 that the glass-ceramic bonds to the living bone through an apatite layer without any distinct boundary among them. This kind of apatite layer was not observed at the interface of non-bioactive glasse ${ }^{20), 22)}$ and glassceramics $^{29)}$ to the bone. This indicates that the essential condition for glasses and glass-ceramics to bond to living bone is formation of an apatite layer on their surfaces in the body.

The apatite layer on the surfaces of bioactive glasses and glass-ceramics is formed even in an acellular simulated body fluid with ion concentrations nearly equal to those of the human blood plasma $\left(\mathrm{Na}^{+}\right.$ 142.0, $\mathrm{K}^{+}$5.0, $\mathrm{Mg}^{2+} 1.5, \mathrm{Ca}^{2+} 2.5, \mathrm{Cl}^{-}$147.8, $\left.\mathrm{HCO}_{3}-4.2, \mathrm{HPO}_{4}{ }^{2-} 1.0, \mathrm{SO}_{4}{ }^{2-} 0.5 \mathrm{mM}\right),{ }^{30)-34)}$ as shown in Fig. 5. According to thin-film X-ray diffraction and Fourier transform infrared reflection spectroscopy of the surface of glass-ceramic A-W ex-

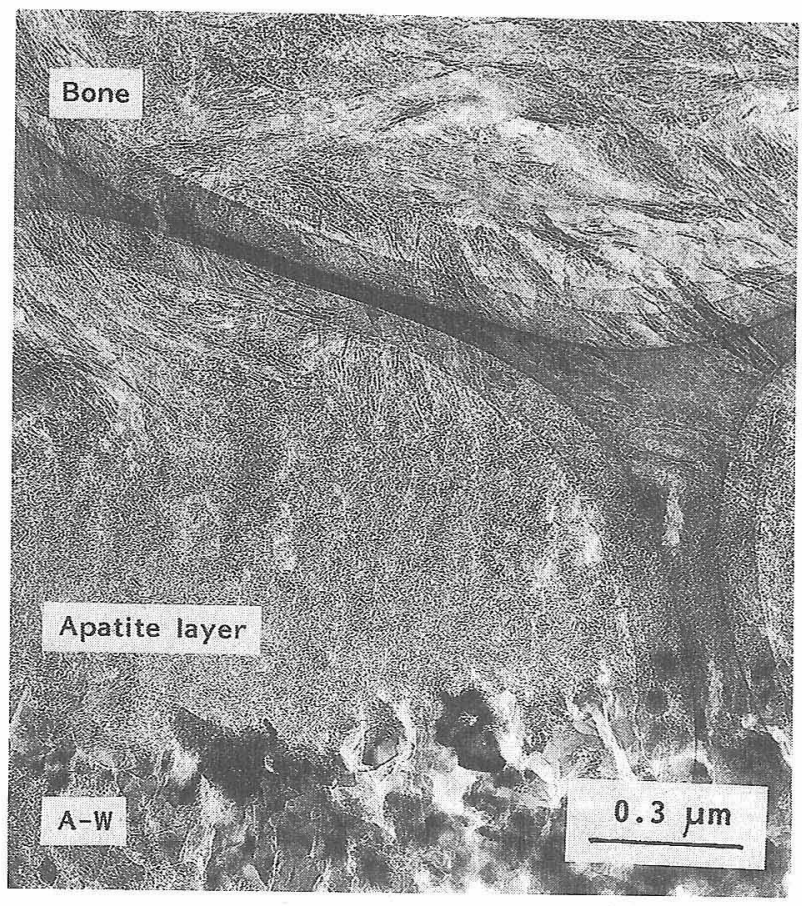

Fig. 4. Transmission electron micrograph of the interface between glass-ceramic A-W and tibial bone of rat. The dark band crossing the photograph is the grid supporting the thin section.

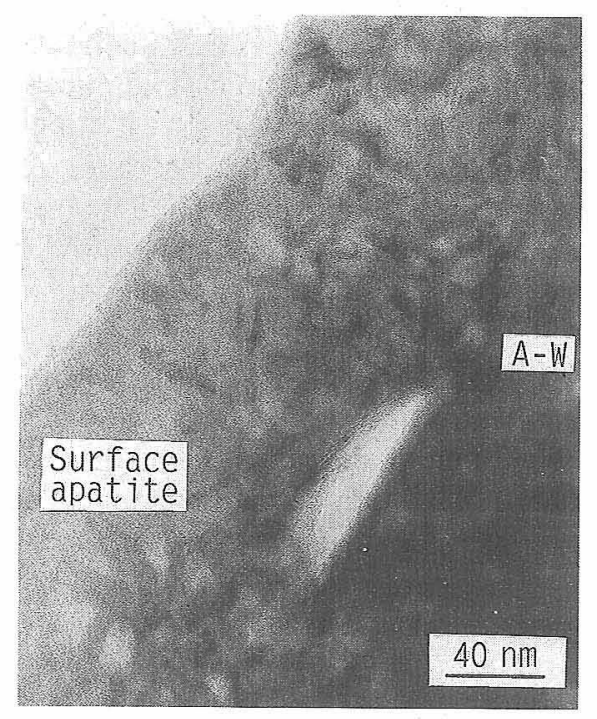

Fig. 5. Transmission electron micrograph of a cross section of apatite layer formed on the surface of glass-ceramic $A-W$ in a simulated body fluid.

posed to the simulated body fluid, the surface apatite layer consists of carbonate-containing hydroxyapatite of defective structure and small crystallites. ${ }^{30), 31)}$ These compositional and structural characteristics are similar to those of the apatite in the bone. Therefore, it can be expected that the osteoblast, i.e. bone-producing cell, could proliferate on the surface of the apatite layer, in preference to the fibroblast, i.e. fibrous tissue-producing cell. Consequently, bioactive glasses and glass-ceramics might contact directly with the surrounding bone 
with no intervention by the fibrous tissue. When this occurs, tight chemical bond might be formed between the surface apatite and the bone apatite, in order to decrease the interface energy between them. When a couple of glass-ceramic $A-W$ were soaked in the simulated body fluid or implanted subcutaneously into rat, they were so tightly bonded together through an apatite layer in one month that they could not be separated by manual force. ${ }^{35), 36)}$ This indicates that a tight chemical bond can be formed between the apatite crystals in the body, even if organic substances take no part.

The simulated body fluid in which glass-ceramic $\mathrm{A}-\mathrm{W}$ was soaked showed first a little increase in the calcium and silicon concentrations in the fluid, and then appreciable decreases in the calcium and phosphorus concentration. ${ }^{37}$ ) This indicates that the nucleation of the apatite on the surface of the glassceramic is induced by the calcium and silicate ions dissolved from the glass-ceramic and growth of the apatite is achieved by consuming the calcium and phosphate ions from the surrounding fluid, as shown in Fig. 6. The dissolved calcium ion might increase the degree of the supersaturation of the surrounding fluid with respect to the apatite, which is already supersaturated even before the implantation of the glass-ceramic. The dissolved silicate ion might provide favorable sites for nucleation of the apatite on the surface of the glass-ceramic. The phosphate ion required for nucleation of the apatite is supplied only from the surrounding fluid. Glass-ceramic A-W (Al) which contains crystalline apatite and wollastonite in a $\mathrm{MgO}-\mathrm{CaO}-\mathrm{SiO}_{2}-\mathrm{Al}_{2} \mathrm{O}_{3}$ glassy matrix did not form the apatite layer on its surface in the simulated body fluid, but did in the simulated body fluid added with a small amounts of the calcium ion in combination with the silicate ions. ${ }^{38)}$ This supports the assumption that the calcium and silicate ions dissolved from glass-ceramic A-W induce the apatite nucleation on the surface of the glass-ceramic.

Figure 7 shows compositional dependence of apatite formation on the surfaces of glasses in the system $\mathrm{CaO}-\mathrm{SiO}_{2}-\mathrm{P}_{2} \mathrm{O}_{5}$ in the simulated body fluid. It can be seen from Fig. 7 that the surface apatite for-
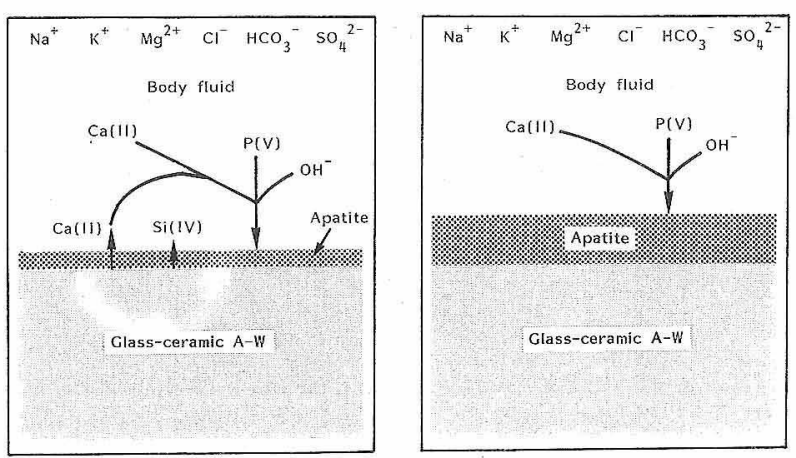

Fig. 6. Mechanism of apatite formation on the surface of glassceramic $\mathrm{A}-\mathrm{W}$ in the body: left, initial stage; right, later stage.

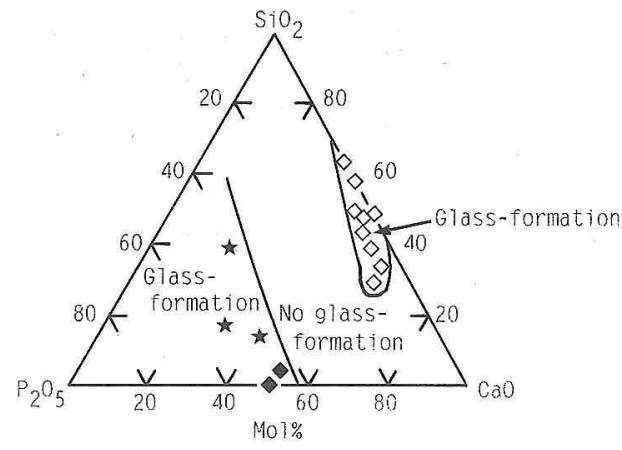

Fig. 7. Compositional dependence of apatite formation on the surfaces of glasses in the system $\mathrm{CaO}-\mathrm{SiO}_{2}-\mathrm{P}_{2} \mathrm{O}_{5}$ in a simulated body fluid (Soaking period: 30 days).

$\diamond:$ Apatite formation, $\diamond:$ No apatite formation, $\$$ : Dissolution.

mation is restricted to the $\mathrm{CaO}, \mathrm{SiO}_{2}$-based compositional region and not observed in the $\mathrm{CaO}, \mathrm{P}_{2} \mathrm{O}_{5^{-}}$ based compositional region. ${ }^{39)}$ Both the calcium ion dissolved from the $\mathrm{CaO}, \mathrm{SiO}_{2}$-based glasses and the phosphate ion dissolved from the $\mathrm{CaO}, \mathrm{P}_{2} \mathrm{O}_{5}$-based glasses increased almost equally the degree of the supersaturation of the surrounding fluid with respect to the apatite, i.e. the difference between the ionic activity product and the solubility product $(5.5 \times$ $\left.10^{-118}\right)^{40)}$ of the apatite in the fluid, as shown in Fig. 8. ${ }^{41)}$ In spite of it, the former glasses formed the surface apatite layer but the latter glasses did not form it. The decrease in the ionic activity product of the apatite for the $\mathrm{CaO}, \mathrm{SiO}_{2}$-based glasses at later stages in Fig. 8 is due to apatite formation on their surfaces. This indicates that the surfaces of the $\mathrm{CaO}$, $\mathrm{SiO}_{2}$-based glasses exclusively provide favorable sites for apatite nucleation. The $\mathrm{CaO}, \mathrm{SiO}_{2}$-based glasses formed a silica hydrogel layer prior to forming the apatite layer and dissolved an appreciable amount of the silicate ion. This means that highly hydrated silica groups are abundant on the surfaces of the glasses. It can be speculated that the highly hydrated silica groups effectively induced heterogeneous nucleation of the apatite. Andersson et al. proposed that complexation of phosphate by hydrated silica gel is the first step for the apatite nucleation

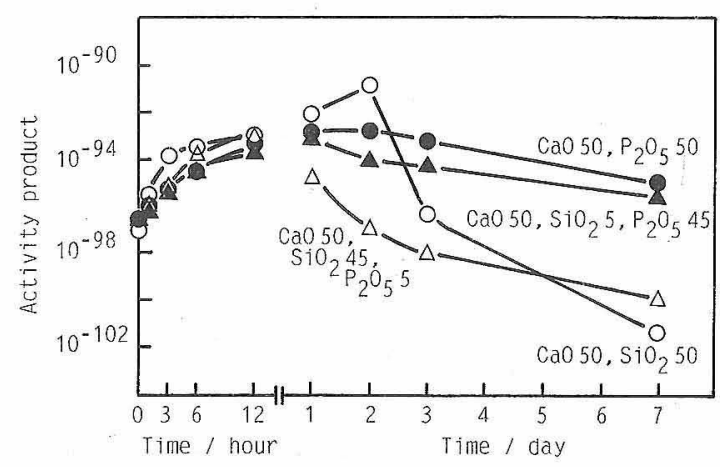

Fig. 8. Changes in ionic activity product of the apatite in the simulated body fluid due to immersion of $\mathrm{CaO}-\mathrm{SiO}_{2}-\mathrm{P}_{2} \mathrm{O}_{5}$ glasses. Glass compositions are given in $\mathrm{mol} \%$. 
on the surfaces of silicate glasses. ${ }^{42)}$

The sintered hydroxyapatite, one of the crystalline calcium phosphate ceramics rich in the calcium, also forms an apatite layer in the body environment, although it lacks in silica. ${ }^{43)}$ The rate of formation of the apatite layer on it is, however, much lower than that on glass-ceramic $A-W, 31)$ because of the lack of the silica. This might be the reason why the rate of bone growth on the surfaces of the sintered hydroxyapatite was much lower than that of glass-ceramics A-W.11) These results indicate that bioactive glasses and glass-ceramics could be obtained from silicate glasses more easily than from phosphate glasses. Bioactive glass-ceramic hitherto prepared from silica-free phosphate composition is only apatite- and $\mathrm{AlPO}_{4}$-containing glass-ceramic in the system $\mathrm{Na}_{2} \mathrm{O}$ $\mathrm{CaO}-\mathrm{Al}_{2} \mathrm{O}_{3}-\mathrm{P}_{2} \mathrm{O}_{5} \cdot{ }^{44}$ )

\section{Bioactive composite}

Even glass-ceramic A-W can not segmentally replace the femur and tibia, because its fracture toughness, $2.0 \mathrm{MPa} \cdot \mathrm{m}^{1 / 2}$, is lower than that of human cortical bone, $6 \mathrm{MPa} \cdot \mathrm{m}^{1 / 2}$ at maximum, and its Young's modulus, $117 \mathrm{GPa}$, is higher than that of the human cortical bone, $30 \mathrm{GPa}$ at maximum.

One of the method for obtaining bioactive materials with high fracture toughnesses is coating bioactive materials on metallic substrates. A Fe-Co-Cr$\mathrm{Ni}$ alloy coated with a Bioglass-type glass is already clinically used as tooth root implant. ${ }^{45)}$ Many trials have been done also for coating hydroxyapatite on metallic substrates using plasma spray method etc. The major limitation of this kind of materials is, however, the long term stability of the interface between the bioactive materials and the metals.

Another method for obtaining bioactive materials with high fracture toughness is incorporating tough fibers or particles into bioactive materials. A Bioglass-type glass reinforced with stainless steel fibers, ${ }^{46)}$ a Ceravital ${ }^{\circledR}$-type glass-ceramic reinforced with titanium particles ${ }^{47)}$ and a A-W-type glass-ceramic reinforced with partially stabilized zirconia particles ${ }^{48)}$ have been reported as the composites based on glasses. Various kinds of composites based on sintered hydroxyapatite have been also reported. Among them, a composite of a $\mathrm{A}-\mathrm{W}$-type glass-ceramic with $30 \mathrm{~mol} \% \quad \mathrm{ZrO}_{2}\left(\mathrm{Y}_{2} \mathrm{O}_{3}\right)$ particles which was prepared by a hot-pressing technique gave the highest bending strength of $600 \mathrm{MPa}$ and fracture toughness of $3.0 \mathrm{MPa} \cdot \mathrm{m}^{1 / 2}$, which are almost comparable to those of the dense sintered alumina, without giving adverse effect on bioactivity. Clinical trials of this composite for tooth root implant are being conducted. Young's modulus of this composite is, however, not as low as that of the natural bone.

Bioactive composite having higher fracture toughness and lower Young's modulus must be approached from different directions. Kokubo et al. recently showed that a continuous and uniform layer of an apatite similar to the bone mineral is formed on the surfaces of any kind of materials including metals, ceramics and organic polymers in any shapes, when they are laid on granular particles of a $\mathrm{CaO}, \mathrm{SiO}_{2}$-based glass in the simulated body fluid for a certain period, and then soaked in a fluid with ion concentrations 1.5 times those of the simulated body fluid for a certain period, as shown in Fig. 9.49),50) In this technique, apatite nuclei are formed on the sur-

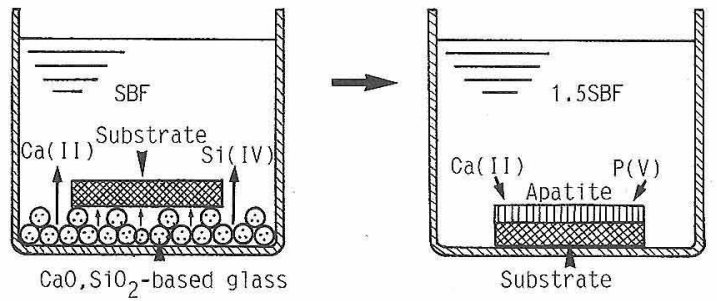

Fig. 9. Nucleation (left) and growth (right) of the apatite on the surface of a substrate.

SBF: Simulated body fluid.
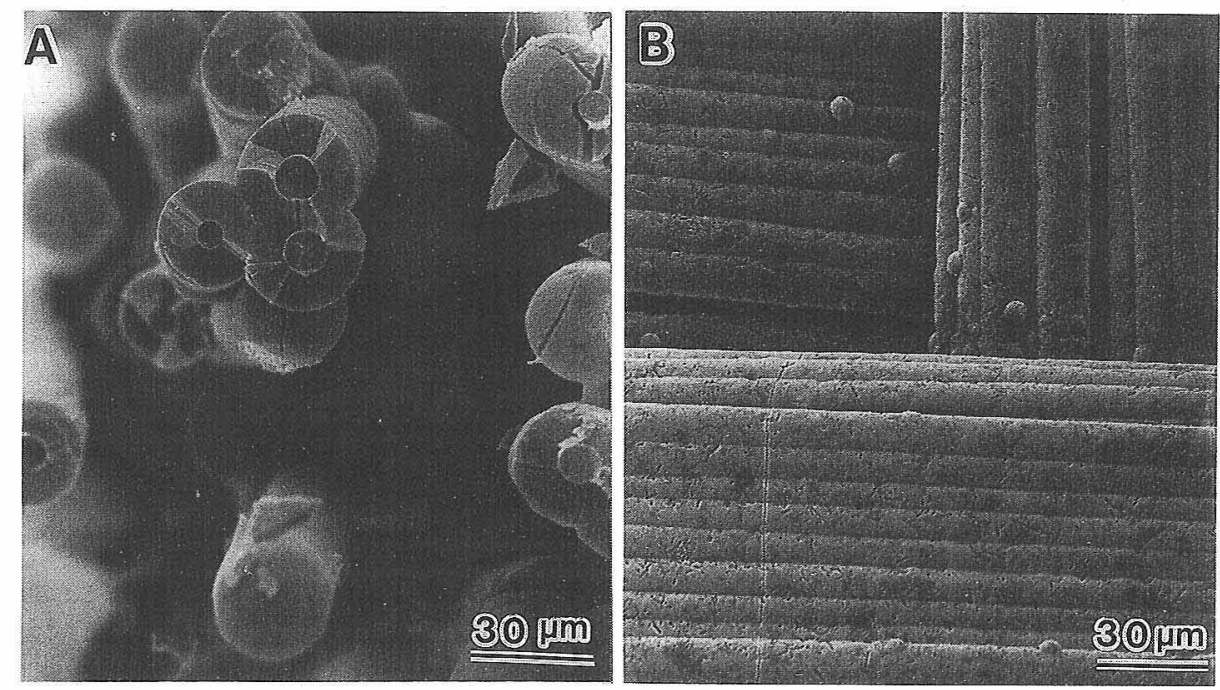

Fig. 10. Apatite layer formed on alumina fiber (A, cross section) and carbon cloth (B). 
face of the substrate during the first soaking by the reaction of the calcium and silicate ions dissolved from the glass grains with the phosphate ion in the fluid, and then thus formed apatite nuclei spontaneously grow during the second soaking by consuming the calcium and phosphate ions from the fluid. The thickness of the apatite layer linearly increases with increasing soaking time in the second fluid at a rate of $7 \mu \mathrm{m} /$ day at $60^{\circ} \mathrm{C}$. Figure 10 shows the apatite layers about $10 \mu \mathrm{m}$ thick formed on alumina single fibers and a carbon cloth. Thus formed apatite is expected to show higher bioactivity than that prepared by the conventional methods using heat treatments, since the former is formed in an environment similar to the living body. This kind of biomimetic technique might be useful for obtaining a highly bioactive composite having mechanical properties close to those of the natural bone.

\section{Bioactive cement}

The result mentioned above, that a couple of glass-ceramic $\mathrm{A}-\mathrm{W}$ bonded together forming an apatite layer on their surfaces in the simulated body fluid, indicates that a bioactive cement which can set in a few minutes and bond to the living bone could be obtained by mixing $\mathrm{CaO}, \mathrm{SiO}_{2}$-based glass powders and phosphate ion-containing solution.

Kolkubo et al. attempted to mix glass powders (about $5 \mu \mathrm{m}$ in size, the nominal composition $\mathrm{CaO}$ $46.7, \mathrm{SiO}_{2} 35.6, \mathrm{P}_{2} \mathrm{O}_{5} 17.0, \mathrm{CaF}_{2} 0.7 \mathrm{wt} \%$ ) with a 3.7 $\mathrm{M}$ ammonium phosphate solution of $\mathrm{pH} 7.4$ with the powder to liquid ratio of $1 \mathrm{~g}$ to $0.5 \mathrm{ml} .{ }^{51)}$ The mixed paste set within 4 min, forming the calcium ammonium phosphate hydrate $\left(\mathrm{CaNH}_{4} \mathrm{PO}_{4} \cdot \mathrm{H}_{2} \mathrm{O}\right)$ at the intergranular spaces of the glass powders. When the cement was soaked in the simulated body fluid, it showed an increase in compressive strength with increasing soaking time, forming a hydroxyapatite $\left(\mathrm{Ca}_{10}\left(\mathrm{PO}_{4}\right)_{6}(\mathrm{OH})_{2}\right)$ in place of the calcium ammonium phosphate hydrate, as schematically shown in Fig. 11. The compressive strength reached $80 \mathrm{MPa}$, 3 to 4 times that of conventional Portland cement, within 3 days. The mixed paste which was implanted into a bone defect of rat tibia directly bonded to the living bone with no intervention of fibrous tissue, as shown in Fig. 12.52) This kind of bioactive cement might be useful for fixing various kinds of implants to the surrounding bone, as well as, by itself, as a bone filler. Polymethyl-methacrylate has been used extensively as the cement for fixing orthopaedic im-

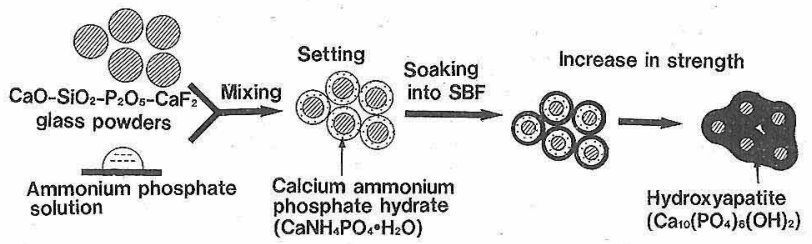

Fig. 11. Mechanism of setting and hardening of bioactive cement of a $\mathrm{CaO}-\mathrm{SiO}_{2}-\mathrm{P}_{2} \mathrm{O}_{5}$ glass.

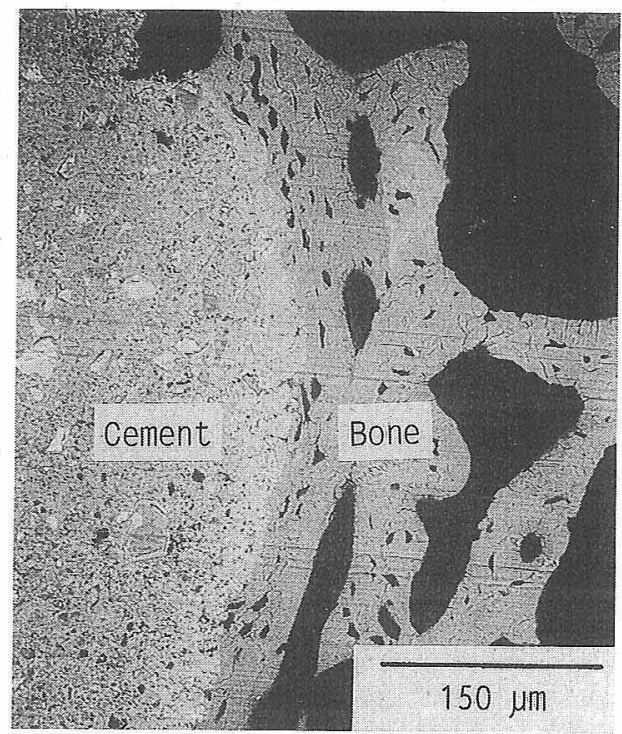

Fig. 12. Interface between bioactive cement implanted into a rat tibia and the surrounding bone (back-scattering electron image, at 4 weeks after implantation).

plants such as total hip prosthesis to the surrounding bone. This cement, however, does not bond to living bone, and hence fixation by this cement is liable to loosen for a long period. Although some attempts have been made to obtain bioactive cement from crystalline calcium phosphate, the resultant cements had some problems with setting time, mechanical strength, stability within the body, and/or biocompatibility.

\section{Glass-ceramics for dental crown}

Materials for dental crown are not required to be bioactive but to be inert within the oral environment. It should be similar to natural tooth in appearance such as color and translucency, and in physical properties such as hardness, elastic modulus, thermal conductivity and thermal expansion coefficient. In addition, it must be easily fabricated and mechanically strong enough for handling. Hitherto, some metals, porcelain-coated metals and composite resins have been mainly used for dental restoration. The metals are, however, not compatible to living tissue, and different from natural tooth in the appearance and physical properties. The porcelain-coated metals require complex techniques for fabrication. The composite resins are not stable in the oral environment. On the other hand, glass-ceramics could fulfill most of the requirements described above. The parent glass can be easily shaped into a form of crown by casting technique. It can be converted into a strong and inert glass-ceramic similar to the natural tooth in the appearance and physical properties by a heat treatment, without causing appreciable change in the dimension, as shown in Fig. 13.

Because of these advantages, various kinds of glass-ceramics for dental crown have been deve- 


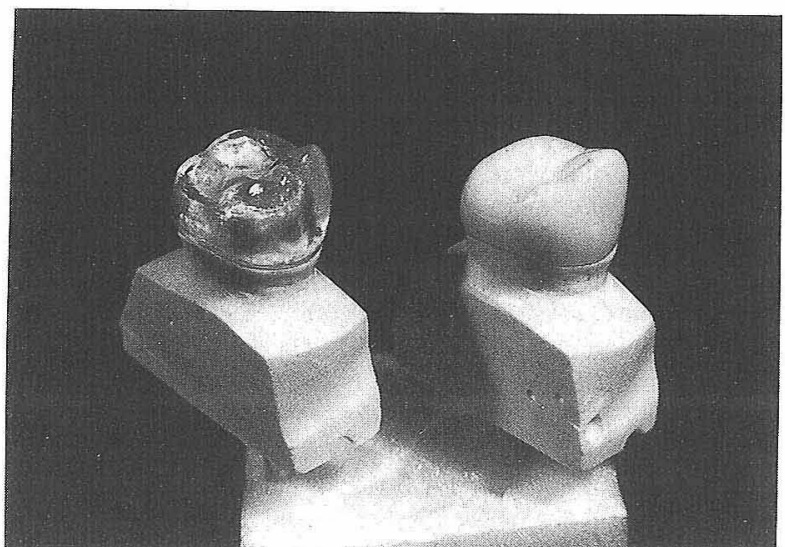

Fig. 13. A $\mathrm{MgO}-\mathrm{CaO}-\mathrm{SiO}_{2}-\mathrm{TiO}_{2}-\mathrm{P}_{2} \mathrm{O}_{5}$ glass shaped into a form of dental crown by casting (left) and its crystallized product containing apatite and magnesium titanate $\left(\mathrm{MgTiO}_{3}\right)$ (right).

loped. Those precipitating phlogopite $\left(\mathrm{K}_{2} \mathrm{Mg}_{2} \mathrm{Si}_{8} \mathrm{O}_{22}\right.$ F), 53) phlogopite $\left(\mathrm{NaMg}_{3}\left(\mathrm{Si}_{3} \mathrm{AlO}_{10}\right) \mathrm{F}_{2}\right)$ and $\beta$-spodumen $\left(\mathrm{Li}_{2} \mathrm{O} \cdot \mathrm{Al}_{2} \mathrm{O}_{3} \cdot 4 \mathrm{SiO}_{2}\right),{ }^{54)} \beta-\mathrm{CaO} \cdot \mathrm{P}_{2} \mathrm{O}_{5},{ }^{55)} \beta-\mathrm{CaO}$. $\mathrm{P}_{2} \mathrm{O}_{5}$ and $\mathrm{AlPO}_{4},{ }^{56)}$ oxyfluorapatite $\left(\mathrm{Ca}_{10}\left(\mathrm{PO}_{4}\right)_{6}(\mathrm{O}\right.$, $\left.\mathrm{F}_{2}\right)$ ), ${ }^{57)}$ apatite and magnesium titanate $(\mathrm{MgTi}$ $\left.\mathrm{O}_{3}\right),{ }^{58)}$ and apatite, $\beta$ - $\mathrm{CaO} \cdot \mathrm{P}_{2} \mathrm{O}_{5}$ and diopside $\left(\mathrm{MgO} \cdot \mathrm{CaO} \cdot 2 \mathrm{SiO}_{2}\right)^{59)}$ are some examples of them. Among them, two kinds of phlogopite-containing glass-ceramics ${ }^{53), 54)}$ are already clinically used and others are under clinically trials.

\section{Glasses and glass-ceramics for cancer treatment}

Glasses and glass-ceramics can play an important role also in cancer treatments. Ehrhardt et al. showed that glass microspheres 20 to $30 \mu \mathrm{m}$ in diameter of the composition $\mathrm{Y}_{2} \mathrm{O}_{3} 40, \mathrm{Al}_{2} \mathrm{O}_{3} 20, \mathrm{SiO}_{2}$ $40 \mathrm{wt} \%$ are useful for radiotherapy. ${ }^{60)}$ Subjected to neutron bombardment, ${ }^{89} \mathrm{Y}$ in the glass is activated to $\beta$-emitter of ${ }^{90} \mathrm{Y}$ with a half-life time of $64.1 \mathrm{~h}$. The glass is insoluble in body fluids and non-toxic. Injected to the liver through the hepatic artery, the glass microspheres are entrapped in the capillary bed of liver tumors and give large local radiation dose of the short-ranged, highly ionizing $\beta$-ray to the tumors, with little irradiation to neighboring organs. It is successfully subjected to clinical trials for liver cancer treatment.

Glass-ceramics containing ferrimagnetic crystalline phases are useful as thermoseeds for hyperthermia treatment of cancer. Cancer cells are destroyed when heated up to $43^{\circ} \mathrm{C}$, where the normal cells are not damaged. Tumor is heated more easily than the normal tissue, because the nervous and vascular systems are not fully developed in the tumor. The hyperthermia is, therefore, an effective cancer treatment with little side effect. There are, however, few effective method for heating the tumor locally, especially for deep-seated tumor. Ferrimagnetic materials can heat the tumor locally by magnetic hysteresis loss, when implanted around the tumor and subjected to an alternating magnetic field, even if the tumor is deeply seated. In glass-ceramics, the ferrimagnetic phase can be embedded in a biocompatible or bioactive matrix. When the matrix is bioactive, the ferrimagnetic glass-ceramics can be bonded together with each other, when implanted in granular forms, as well as to the bone, forming an apatite layer on their surfaces, to be fixed stably around the tumor.

A glass-ceramic containing lithium ferrite $\left(\mathrm{LiFe}_{5}\right.$ $\left.\mathrm{O}_{8}\right)$ in a biocompatible matrix of hematite $\left(\alpha-\mathrm{Fe}_{2} \mathrm{O}_{3}\right)$ and $\mathrm{Al}_{2} \mathrm{O}_{3}-\mathrm{SiO}_{2}-\mathrm{P}_{2} \mathrm{O}_{5}$ glassy phase, ${ }^{61)}$ and that containing magnetite $\left(\mathrm{Fe}_{3} \mathrm{O}_{4}\right)$ in a bioactive matrix of $\beta$-wollastonite and a $\mathrm{CaO}-\mathrm{SiO}_{2}-\mathrm{B}_{2} \mathrm{O}_{3}-\mathrm{P}_{2} \mathrm{O}_{5}$ glassy phase ${ }^{62), 63)}$ have been developed for this purpose. The former shows a saturation magnetization of $8.69 \mathrm{emu} / \mathrm{g}$ and a coercive force of 182 Oe. Powders of this glass-ceramic which were injected into a thigh of mouse were confirmed to destroy a transplanted breast cancer, when subjected to an alternating magnetic field of $10 \mathrm{kHz}$ and 500 Oe for $2 \mathrm{~h}$.

Figure 14 shows a transmission electron micrograph of the magnetite-containing glass-ceramic. This glass-ceramic contains $36 \mathrm{wt} \%$ of the magnetite $200 \mathrm{~nm}$ in size, to show a saturation magnetization of $32 \mathrm{emu} / \mathrm{g}$ and a coercive force of $120 \mathrm{Oe}$. Granular particles 2 to $3 \mathrm{~mm}$ in diameter of this glass-ceramic which were implanted into a bone marrow of rabbit tibia could heat the outside of the cortical bone up to $43^{\circ} \mathrm{C}$ in $5 \mathrm{~min}$, after subjected to an alternating magnetic field of $100 \mathrm{kHz}$ up to $300 \mathrm{Oe}$, as shown in Fig. 15. ${ }^{64)} \mathrm{A}$ pin $3 \mathrm{~mm}$ in diameter and 50 $\mathrm{mm}$ in length of this glass-ceramic which was inserted into a medullary canal of rabbit tibia completely killed cells of transplanted bone tumor, when subjected to the alternating magnetic field for $50 \mathrm{~min} .{ }^{65}$ )

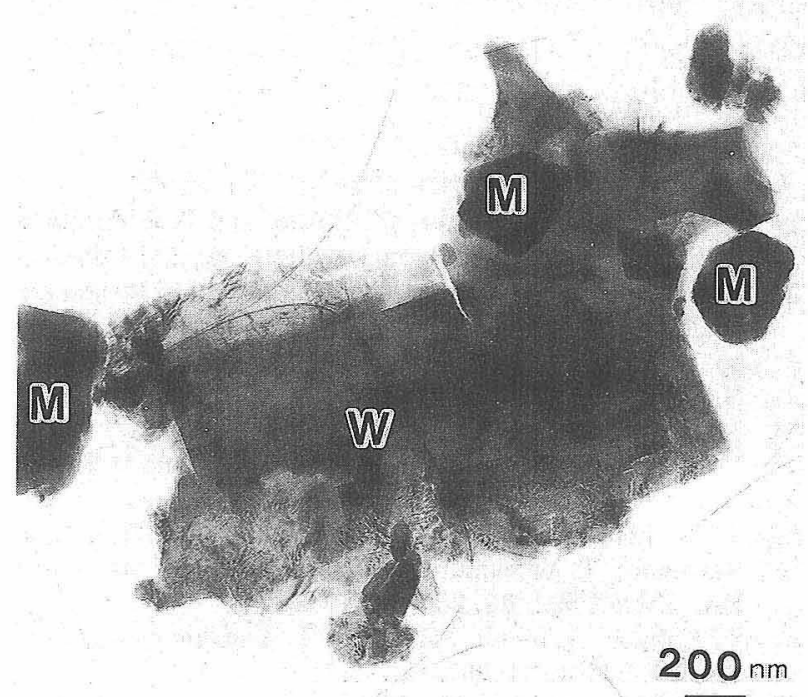

Fig. 14. Transmission electron micrograph of a bioactive and ferrimagnetic glass-ceramic containing magnetite $(M)$ in a matrix of $\beta$-wollastonite $(\mathrm{W})$ and a $\mathrm{CaO}-\mathrm{SiO}_{2}-\mathrm{B}_{2} \mathrm{O}_{3}-\mathrm{P}_{2} \mathrm{O}_{5}$ glassy phase. 


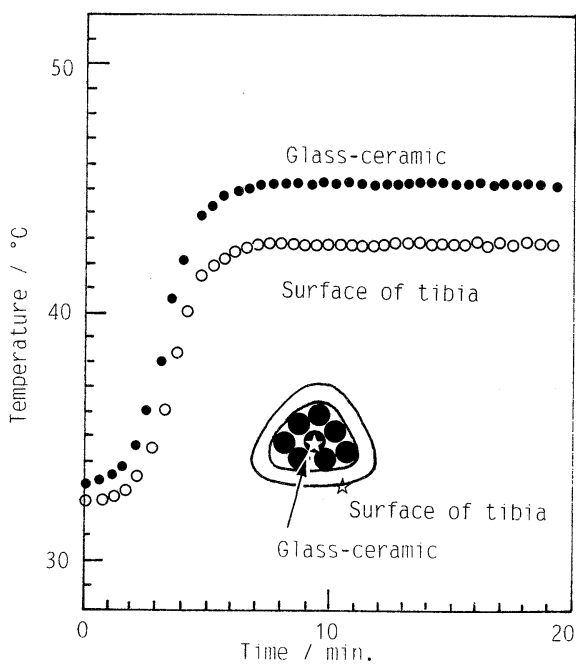

Fig. 15. Temperature rise at outer surface of tibia of rabbit due to exposure to an alternating magnetic field. The strength of the magnetic field was controlled so that the temperature at the middle of the glass-ceramics was maintained at $45^{\circ} \mathrm{C}$.

\section{Conclusion}

It is apparent from the examples described above that various kinds of novel biomedical materials can be derived from glasses. Glass can be changed continuously and widely in the composition. Glass can be crystallized with controlled sizes and contents of the crystalline phases. Glass can be variously modified with surface treatments. Therefore, glass can be tailored for specific applications in wide range of biomedical field. Applications of glasses and glassbased materials have been hitherto mainly directed toward the repairing hard tissues such as bones and teeth. They could, however, play an important role also in repairing soft tissues. They could not only replace the damaged living tissue, but also aid or enhance self-repairing activity of living tissues, by combining with biological components. Glasses and glass-based materials will occupy more important position in biomedical materials in the next decade.

\section{References}

1) L. L. Hench, R. J. Splinter, W. C. Allen and T. K. Greenlee J. Biomed. Mater. Res. Symp., 2 (1971) pp. 117-41.

2) J. Wilson, “Glass: Current Issues”, Ed. by A. F. Wright and J. Dupuy, Martinus Nijhoff Publishers, Dordrecht (1985) pp. 662-69

3) H. Brömer, E. Pfeil and H. H. Kos, German Patent No. 2,326,100 (1973).

4) H. Brömer, K. Deutscher, B. Blenke, E. Pfeil and V. Strunz Science of Ceramics, 9, 219-25 (1977)

5) T. Kokubo, M. Shigematsu, Y. Nagashima, M. Tashiro, T Nakamura, T. Yamamuro and S. Higashi, Bull. Inst. Chem. Res., Kyoto Univ., 60, 260-68 (1982).

6) T. Kokubo, S. Ito, S. Sakka and T. Yamamuro, J. Mater. Sci., 21, 536-40 (1986)

7) T. Kokubo, S. Ito, M. Shigematsu, S. Sakka and T. Yamamuro, J. Mater. Sci., 20, 2001-04 (1985).

8) T. Kokubo, S. Ito, M. Shigematsu, S. Sakka and T. Yamamuro, J. Mater. Sci., 22, 4067-70 (1987).
9) M. Jarcho, J. F. Kay, K. I. Gumaer, R. H. Doremus and H. P. Drobeck, J. Bioeng., 1, 79-92 (1977).

10) T. Nakamura, T. Yamamuro, S. Higashi, T. Kokubo and S. Ito, J. Biomed. Mater. Res., 19, 685-98 (1985).

11) K. Ono, T. Yamamuro, T. Nakamura and T. Kokubo, Biomaterials, 11, 265-71 (1990).

12) T. Yamamuro, J. Shikata, H. Okumura, S. Yoshii, S. Kotan and T. Kokubo, "Bioceramics", Vol. 2, Ed. by G. Heimke, German Ceramic Society, Cologne (1990) pp. 361-66.

13) T. Yamamuro, J. Shikata, H. Okumura, T. Kitsugi, Y. Kakutani, T. Matsui and T. Kokubo, J. Bone and Joint Surgery, 72-B, 889-93 (1990).

14) K. Ono, T. Yamamuro, T. Nakamura and T. Kokubo, J. Biomed. Mater. Res., 24, 11-20 (1990).

15) G. Berger, R. Sauer, G. Steinborn, F. G. Wihsmann, V. Thieme, St. Köhler and H. Dressel, "Proceedings of XV International Congress on Glass", Vol. 3a, Ed. by O. V. Mazurin, Nauka, Leningrad (1989) pp. 120-26.

16) W. Höland, J. Naumann, W. Vogel and J. Gummel, Wiss, Z. Freidrich Schieler Univ. Jena Math. Naturwiss, Reihe, 32, 571-80 (1983).

17) J. Gummel, H. Zippel and H. Hähnel, Z. Klin. Med., 43, 1791-93 (1988).

18) L. L. Hench, "Fundamental Aspects of Biocompatibility", Vol. 1, Ed. by D. F. Williams, CRC Press, Boca Raton (1981) pp. 67-85.

19) L. L. Hench and A. E. Clark, "Biocompatibility of Orthopaedic Implants", Vol. 2, Ed. by D. F. Williams, CRC Press, Boca Raton (1982) pp. 129-70.

20) T. Kitsugi, T. Yamamuro, T. Nakamura and T. Kokubo, $J$ Biomed. Mater. Res., 23, 631-48 (1989).

21) K. Ohura, T. Nakamura, T. Yamamuro, T. Kokubo, Y Ebisawa, Y. Kotoura and M. Oka, J. Biomed. Mater. Res., 25, 357-65 (1991).

22) K. Ohura, T. Nakamura, T. Yamamuro, Y. Ebisawa, T. Kokubo, Y. Kotoura and M. Oka, Materials in Medicine, in press.

23) T. Kitsugi, T. Yamamuro, T. Nakamura, S. Hayashi, Y. Kakutani, K. Hyakuna, S. Ito, T. Kokubo, M. Takagi and T. Shibuya, J. Biomed. Mater. Res., 20, 1295-307 (1986).

24) T. Kitsugi, T. Nakamura, T. Yamamuro, T. Kokubo, T. Shibuya and M. Takagi, J. Biomed. Mater. Res., 21, 1255-71 (1987).

25) S. Kotani, T. Yamamuro, T. Nakamura, T. Kitsugi, Y. Fujita, K. Kawanabe, T. Kokubo and C. Ohtsuki, "Bioceramics" Vol. 2, Ed. by G. Heimke, German Ceramic Society, Cologne (1990) pp. 105-12.

26) W. Höland, W. Vogel, K. Naumann and J. Gummel, J. Biomed. Mater. Res., 19, 303-12 (1985).

27) T. Kokubo, C. Ohtsuki, S. Kotani, T. Kitsugi and T. Yamamuro, "Bioceramics", Vol. 2, Ed. by G. Heimke, German Ceramics Society, Cologne (1990) pp. 113-20.

28) M. Neo, S. Kotani, Y. Fujita, T. Nakamura, T. Yamamuro, Y. Bando, M. Yokoyama, C. Ohtsuki and T. Kokubo, "Bioceramics", Vol. 4, Ed. by W. Bonfield, G. W. Hastings and K. E. Tanner, Butterworth-Heinemann, Guilford (1991) in press.

29) T. Kitsugi, T. Yamamuro, T. Nakamura and T. Kokubo, International Orthopaedics, 13, 199-206 (1989).

30) T. Kokubo, T. Hayashi, S. Sakka, T. Kitsugi, T. Yamamuro, M. Takagi and T. Shibuya, "Ceramics in Clinical Application", Ed. by P. Vincenzini, Elsevier, Amsterdam (1989) pp. 175-84.

31) T. Kokubo, S. Ito, Z. T. Huang, T. Hayashi, S. Sakka, T. Kitsugi and T. Yamamuro, J. Biomed. Mater. Res., 24, 33143 (1990)

32) T. Kokubo, H. Kushitani, S. Sakka, T. Kitsugi and T. Yamamuro, J. Biomed. Mater. Res., 24, 721-34 (1990).

33) C. Ohtsuki, H. Kushitani, T. Kokubo, S. Kotani and T. Yamamuro, J. Biomed. Mater. Res., 25 (1991) in press. 
34) Y. Ebisawa, T. Kokubo, K. Ohura and T. Yamamuro, Materials in Medicine, 1, 239-44 (1990).

35) T. Kokubo, T. Hayashi, S. Sakka, T. Kitsugi and T. Yamamuro, Yogyo-Kyokai-Shi (J. Ceram. Soc. Jpn), 95, 78591 (1987)

36) T. Kitsugi, T. Yamamuro, T. Nakamura, T. Kokubo, M. Takagi, T. Shibuya, H. Takeuchi and M. Ono, J. Biomed. Mater. Res., 21, 1109-23 (1987).

37) C. Ohtsuki, T. Kokubo and T. Yamamuro, to be published.

38) T. Kokubo, J. Non-Cryst. Solids, 120, 138-51 (1990).

39) C. Ohtsuki, T. Kokubo, K. Takatsuka and T. Yamamuro, Seramikkusu Ronbunshi (J. Ceram. Soc. Jpn), 99, 1-6 (1991).

40) H. McDowell, T. M. Gregory and W. E. Brown, J. Res. Natl. Bur. Stand., 81A, 273-81 (1977).

41) C. Ohtsuki, T. Kokubo and T. Yamamuro, J. Non-Cryst. Solids, submitted.

42) O. H. Andersson and K. H. Karlsson, J. Non-Cryst. Solids, 119, 290-96 (1990).

43) T. Kokubo, H. Kushitani, Y. Ebisawa, T. Kitsugi, S. Kotani, K. Ohura and T. Yamamuro, "Bioceramics", Vol. 1, Ed. by H. Oonishi, H. Aoki and K. Sawai, Ishiyaku EuroAmerica, Tokyo (1989) pp. 157-62.

44) W. Vogel and W. Höland, Angew. Chem. Int. Ed. Engl., 26, 527-44 (1987).

45) M. Fujino and M. Ogino, "Oral Implantology and Biomaterials", Ed. by H. Kawahara, Elsevier, Amsterdam (1989) pp. 145-49.

46) P. Ducheyne and L. L. Hench, J. Mater. Sci., 17, 595-606 (1982).

47) Ch. Muller-Mai, H. J. Schmitz, V. Strunz, G. Fuhrmann, Th. Fritz and U. M. Gross, J. Biomed. Mater. Res., 23, 114968 (1989).

48) T. Kasuga and K. Nakajima, "Bioceramics", Vol. 2, Ed. by G. Heimke, German Ceramic Society, Cologue (1990) pp. 303-10.

49) Y. Abe, T. Kokubo and T. Yamamuro, Materials in Medicine, 1, 233-38 (1990).

50) T. Kokubo, K. Hata, T. Nakamura and T. Yamamuro, "Bioceramics", Vol. 4, Ed. by W. Bonfield, G. W. Hastings and K. E. Tanner, Butterworth-Heinemann, Guilford (1991) in press.

51) T. Kokubo, S. Yoshihara, N. Nishimura, T. Yamamuro and
T. Nakamura, J. Am. Ceram. Soc., 74, 1739-41 (1991).

52) N. Nishimura, T. Nakamura, T. Yamamuro and T. Kokubo, "Bioceramics", Vol. 4, Ed. by W. Bonfield, G. W. Hastings and K. E. Tanner, Butterworth-Heinemann, Guilford (1991) in press.

53) P. J. Adair and D. G. Grossman, Int. J. Periodont. Restor. Dent., 4, 33-45 (1984).

54) Y. Hata, H. Suzuki, H. Iijima, H. Yamazaki, H. Iwashita, Y. Hakamatsuka and K. Watanabe, J. Jpn. Prosthodont. Soc., 32, 52-61 (1988).

55) T. Manabe, M. Shigematsu and S. Kobayashi, "Ceramics in Clinical Applications", Ed. by P. Vincenzini, Elsevier, Amsterdam (1987) pp. 63-72.

56) S. Yokotsuka, A. Shinya, T. Kawazoe, K. Suese, A. Watanabe and S. Kihara, The Quintessence, 8, 1595-611 (1989).

57) S. Hobo and T. Iwata, Quintessence Internal., 3, 14-23 (1985).

58) T. Kokubo, S. Sakka, M. Sako and S. Ikejiri, Seramikkusu Ronbunshi (J. Ceram. Soc. Jpn), 97, 239-44 (1989).

59) T. Hino and T. Maruyama, Seramikkusu (Ceramics), 24 608-13 (1989).

60) G. J. Ehrhardt and D. E. Day, Nucl. Med. Biol., 14, 233-42 (1987).

61) A. A. Luderer, N. F. Borrelli, J. N. Panzarino, G. R. Mansfield, D. M. Hess, J. L. Brown and E. H. Barnett, Radiation Res., 94, 190-98 (1983).

62) Y. Ebisawa, Y. Sugimoto, T. Hayashi, T. Kokubo, K. Ohura and T. Yamamuro, Seramikkusu Ronbunshi (J. Ceram. Soc. Jpn), 99, 7-13 (1991).

63) T. Kokubo, Y. Ebisawa, Y. Sugimoto, M. Kiyama, K. Ohura, T. Yamamuro, N. Hiraoka and M. Abe, "Proceedings of 3rd International Symposium on Ceramics in Medicine", Terre Haute, November 18-20 (1990) in press.

64) K. Ohura, M. Ikenaga, T. Nakamura, T. Yamamuro, Y Ebisawa, T. Kokubo, Y. Kotoura and M. Oka, J. Appl. Biomater., in press.

65) M. Ikenaga, K. Ohura, T. Nakamura, Y. Kotoura, T. Yamamuro, M. Oka, Y. Ebisawa and T. Kokubo, "Bioceramics", Vol. 4, Ed. by W. Bonfield, G. W. Hastings and K. E. Tanner, Butterworth-Heinemann, Guilford (1991) in press.

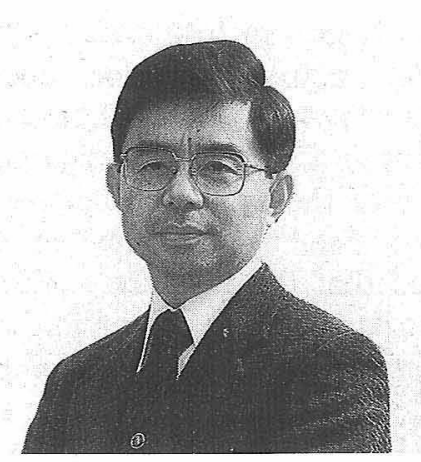

Tadashi KOKUBO is Professor of Materials Science at Institute for Chemical Research, Kyoto University. He received his $\mathrm{Ph.D.} \mathrm{in} \mathrm{Industrial} \mathrm{Chemistry} \mathrm{from}$ Kyoto University in 1970 and his B.Sc. degree in Earth Science from Osaka City University in 1962. He joined Institute for Chemical Research, Kyoto University in 1962 as research associate and was promoted to Associate Professor in 1974 and Full Professor in 1987. He has been working on infrared-transmitting or alkali-resistant glasses and ferrimagnetic, ferroelectric, electrooptic or photoconductive melt- or glass-derived materials. In recent years, his research has concentrated on glasses and glass-based materials for biomedical applications. 